\title{
ISTORIJA
}

\section{LIETUVIỤ TAUTOS SOLIDARUMO RAIŠKA 1905 METAIS}

Prof. Habil. Dr. Antanas Tyla

Lietuvos mokshlı akademija

The Lithuanian Academy of Sciences

El. paštas antanastyla@freemail.lt

\section{Santrauka}

Autorius, primindamas, kad nors 1905 m. tautines revoliucijos, arba sukilimo Lieturoje (tekste-sukilimo), istoriografija nera gausi, is esmès jau yra išaiškinti jo etapai, pugrindinés kovos prieš Rusijos engimq ir už išsilaisvinima formos, ju teritorine sklaida ir pasekmes likviduojant Rusijos valdžios administracijos funkcionavima, išaiškinti to sukilimo vietiniai vadovai, sakilimo slopinimas, represijos ${ }^{l}$, monografiškai yra apdorota Didžiojo Vilnians Seimo istorija ${ }^{2}$. Tačiau, pabrëzădamas, jog mokslo ir istoriografijos raida bei galimybès kelia vis nauju šio ị̂ykio pažinimo ir jvertinimo klausimu, dabar, kai nera ideologines prievanos, galima objektyviai ir aiškiau plèsti sio sukilimo studijas gilyn ir platyn.

Siame straipsmyje aptarsime lienuvil tautos ir ja remianciuju interest! $1905 \mathrm{~m}$. bendruma, solidanmo teritorinẹ ir idejinę sklaidq, solidarumo turinio tradiciškum ir naujumą.

Reikšminiai žodžiai: 1905 metụ sukilimas; tautinis solidarumas; delegatai.

1 Tyla, A. 1905 metu revolincija Lient'os kaime, Vilnitus, 1968; Tyla, A. Lictuvos valdymo 190(1)-1914 metais ypatumai. Lienwos TSR Moksth akadkmijos darboi, A serija. 1968, t. 2, p. $75-94$.

2 Motieka, E. Didysis Vilniaus Scimas. Lieturin atgimimo isforijos studijos. Vilnius, 1996, t. 11. 
1905 m. ịvkiụ tyrimai ir amžininkụ atsiminimai patvirtina, kad beveik visą Lietuvą apèmęs sukilimas, taip ir nesukūręs vadovaujančio sukilimo centro, kaip kad buvo per 1863 m. sukilimą, rèmési idèjiniu solidarumu. Solidarumas tarptautinių žodžiụ žodyne apibūdinamas kaip bendruomeniškumas, vieningumas, interesų bendrumas, bendra atsakomybè.

Tokie solidarumo idealai lydèjo XIX a. vykusius Italijos, Vokietijos ir Čekijos susivienijimus, vieningos tautinès valstybẻs sukūrimą. Idẻjiniu solidarumu buvo paremtas savo vadovaujantị centrą turẻjęs $1863 \mathrm{~m}$. sukilimas. Vincas Kudirka pačioje XIX a. pabaigoje parašytoje „Tautiškoje giesmeje $e^{\text {si }}$ kvietẻ j̣ vienybę vardan tos Lietuvos. Turint galvoje, kad ir dabar dar daugelis nemoka atmintinai Himnu tapusios šios Giesmès, tai $1905 \mathrm{~m}$. iš viso mažai kas žinojo jos turinị, nors tais metais prasidèjusiuose koncertuose ,Tautiška giesmè ${ }^{\text {“ }}$ publikai prašant buvo kartojama po 2-4 kartus ${ }^{3}$. Be abejo, 1905 metụ sukilimo solidarumas ir jo mentalitetas galējo būti lemtas tik kasdienybẻje išaugusių ir susiformavusių troškimų bei siekių juos ịgyvendinti.

Bendri interesai Lietuvoje atsirado ne staiga, bet formavosi per ilgametị pasipriešinimą Rusijos jungui ir pasipriešinimo apibendrinimą atskirų visuomenès grupiu politinèse programose. Visiems žinoma, kad $\mathrm{XIX}$ a. pabaigoje $-\mathrm{XX}$ a. pradžioje Rusijos engiama lietuvių tauta buvo apsibréžusi savo, kaip siuzereno, ribas. Neturẻdama savo valstybès ir priešindamasi Rusijos valdžios vykdomam lietuviškos spaudos, rašto ir kalbos draudimui ir persekiojimui, ji išreiškẻ save kaip lietuvių kalbos siuzerenas ir ją gynè. Knygnešiai, jụ vienijimasis j̣ organizacijas, draudžiamos literatūros kūryba, platinimas ir skaitymas, slaptos lietuviškos mokyklos, jụ daraktoriai radosi iš lietuviụ intelektualinio ir konfesinio poreikio. Knygnešiai, neskaitant inteligentijos, pirmieji pajuto bendrą rūpestị dél lietuviụ kalbos gynimo. Šis atsakomybés suvokimas kaimų,

3 Maciūnas, V. Lietuwes Himno istorijos bruožni. Lietwos Mimnas. Vilnius, 2005, p. 21, 23-25. 
valsčiụ, parapijụ mastu buvo igyvendinamas rašant kolektyvines peticijas Rusijos valdžiai dẻl spaudos draudimo panaikinimo. Po jomis pasirašydavo dešimtys ir net šimtai tam tikro teritorinio vieneto lietuvių. Tarp pasiraŠančiujụ buvo ir moterų, tai patvirtino tautos interesụ integralumą. Skaitydami Rusijos cenzūros nepaliestą draudžiamą lietuvišką literatūrą ir spaudą, gyventojai formavo bendrą požiūrị apie save, apie lietuvių kalbą, rašțą ir apie juos engiančią Rusijos valdžią. Prasidẻjus $19015 \mathrm{~m}$. Rusijos imperijoje revoliucijai, lietuviškos spaudos draudimas jau buvo panaikintas, tačiau juos engusi Rusijos valdžia tebebuvo, ir dabar prieš ją sukilo pati Rusija.

Kaip žinome, per $1905 \mathrm{~m}$. sukilimą idéjinis, mentalinis solidarumas buvo pagrindinis visụ to sukilimo ivykiụ stimuliatorius, pavadavęs nesudarytą sukilimo vadovybę+ Net Didysis Vilniaus Seimas, prièmęs Rusijos imperijos režimo griovimo programą, jos vykdymą pavedẻ valsčiams, pasikliaudamas gyventojụ vieningumu. Vengiant represijụ, vadovaujantis kontrolinis centras nebuvo sudarytas.

$1905 \mathrm{~m}$. kryptingus bendrus išsivadavimo veiksmus ir turinị skatino keli savi ir imperijos valdžios veiksniaj:

1. Rusijos valdžios pertvarkos méginimas ir jo panaudojimas tautiniam išsivadavimui;

2. Inteligentụ ir kaimo aktyvistụ, šviesuoliụ propaganda mitinguose, skrajučiụ platinimas;

3. Didžiojo Vilniaus Seimo organizavimas;

4. Didžiojo Vilniaus Seimo dalyvių gautas tautos pasitikéjimo mandatas, nutarimų autoritetas ir jų igyvendinimo plétra.

Rusijos caro 1905 m. vasario 18 d. [s.st.] manifestas ir ịsakas Senatui, kuriais buvo leista teikti pasiūlymus vyriausybei, generalgubematoriams, gubernatoriams dẻl režimo aparato tobulinimo ir liaudies būklès gerinimo ${ }^{*}$, panašiai kaip Gorbačiovo vadinamoji pertvarka, sudariusi gali-

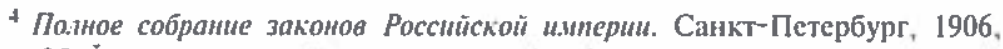
T. 25 . Š is jsakas buvo ats̃auktas $1905 \mathrm{~m}$. birželio $19 \mathrm{~d}$. manifestu, skelbusiu apie Dümos sušaukimịt. 
mybes sovietinès imperijos griūčiai, taip ir manifestas pasitarnavo imperijos režimo kritikai ir jos krizei. Padèties gerinimą dauguma lietuvių suprato kaip Rusijos kolonijinès sistemos Lietuvoje panaikinimą. Aktyviausiai ị šitokị reformos kelią j̦sijungẻ kaimo žmonès ir inteligentija. Savo siülymus valstiečiai svarstè valsčių valdybose, surašydavo juos peticijose, valsčių nutarimuose, priimtuose nedalyvaujant rusụ valdžios pareigūnams, ir siųsdavo Rusijos valdžiai. Jie reikalavo: nevaržomo valsčiaus pareigūnų rinkimo, jụ atsakingumo rinkẻjams, o ne viršininkams; ¡vesti lietuviụ kalbą valsčiụ valdybose ir teismuose, žodžio, spaudos, susirinkimų, organizacijų laisvés; visuotiniais, tiesioginiais, slaptais rinkimajs išrinkto Steigiamojo Seimo arba Seimo Vilniuje sušaukimo. Kybartழ valsčiaus peticijoje vidaus reikalu ministrui vienareikšmiškai ir kategoriškai pabréžiama: „Lietuviụ tauta neteko pasitikẻjimo biurokratiška valdžia, ir vien tik laisvai mūsų išrinkti atstovai su Steigiamojo balso teisèmis, sujungę valstybés valdžią su liaudimi, gali išgelbéti mus, Lietuvos valstiečius, iš vergiškos, beteisiškos, vargingos padėties $^{\text {ts5 }}$. Tokios ir kitokios peticijos, taikančios j Rusijos valdžios ir politinès santvarkos pagrindus, išgąsdino ją, todèl tokius klausimus svarstyti buvo uždrausta ${ }^{6}$. Bet džinas jau buvo išleistas. Viešas engimo svarstymas buvo gera mokykla, ị kurią rinkosi visos Lietuvos valsčiai ir vieni nuo kitụ perémé savo kasdienio gyvenimo demokratizavimo patirti.

Bendrų interesụ ir jụ igyvendinimo büdų propaganda, o kartu ir nauja pasipriešinimo forma buvo $1905 \mathrm{~m}$. pavasarị prasidẻję ir vasarą išptitę mitingai. Daugiausia jų buvo po Didžiojo Vilniaus Seimo. Mitingų or-

5 Walki chlopow Królestwa Polskiego w rewolucji 1905-1907. Warstawa, 1958, 1. 1, p. 766 .

${ }^{6}$ Rusijos policijos vadas Trepovas $1905 \mathrm{~m}$. biržclio $29 \mathrm{~d}$. slaptu aplinkraščciu ịsakč gubernatoriams, micstụ viršininkams ir oberpolicmeisteriams griežtai kontroliuoti susirinkimuose svarstomus klausimus del valstybés valdymo reorganizavimo ir neleisti swarstyti klausimų, kurie yra priç̌ingi režimo pagrindams (LI/A. F. 378, BS, 19015 , b. 1, lap. 33). 
ganizatoriai pasinaudodavo šventadieniais, kai žmonės rinkdavosi ị bažnyčiı̨, arba turgadieniais. Mitingų metu vasarą ir rudenị dar iki Didžiojo Vilniaus Seimo buvo aiškinama politiné padètis, kviečiama versti valdžią, neiti ị kariuomenę, nemokèti mokesčių, neklausyti valdžios nurodymụ. Kartu prasidẻjo visagalés rusụ policijos užpuldinẻjimai, jụ žeminimas. Rudeniop Žemaitijoje, Aukštaitijoje, Suvalkijoje jos veikla buvo paralyžuota. Kartais mitingu metu buvo šalinami iš Rusijos atsiųsti valsčių raštininkai, mokytojai, vietoj jụ renkami lietuviai. Po Didžiojo Vilniaus Seimo mitingai tapo jo nutarimụ igyvendinimo forumais, apèmusiais visą Lietuvą.

Rusijos valdžią labiau negu peticijụ rengimas išklibino caro spalio 17 d. manifestas dél žodžio, susirinkimụ, spaudos ir organizacijų laisvés. Pasimeté ir pati rusų administracija, nebežinojo, ką drausti, ką leisti. Ji pati dar labiau pakriko, nors tuoj po to Suvalkų gubernijos lietuviškose apskrityse buvo ịvesta karo padètis, o Kauno gubernijoje išsaugota nepaprastoji padétis.

Pasinaudodami šiuo manifestu, Panevéžio aps. Čpénų valsčiaus gyventojai nušalino buvusius ir išrinko naujus valsčiaus pareigūnus, pareikalavo, kad bûtụ sušauktas Vilniaus Seimas, o iki jo sušaukimo nutare valdytis patys, tai yra paskelbè savivaldą ir nutraukè ryšius su valdžia. Valsčiaus nutarimai buvo paskelbti „Vilniaus žiniose" ir padarẻ didelị

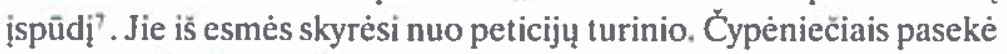
gretimas Girsūdụ valsčius.

Inteligentijos ir liaudies masių tarpusavio supratimas ir pasitikejimas ryškiausjai pasireiškẻ Lietuviụ suvažiavimo Vilniuje, arba Diđžiojo Vilniaus Seimo, rengimo ir jo paties metu. „Vilniaus žiniose“ tik paskelbus Lietuviụ suvažiavimo organizacinio komiteto pirmininko Jono Ba-

${ }^{7}$ Tyla, A. 1905 mety revolincija Lieturos kaime. Vilnjus, 1968, p. 96-97. 
sanavičiaus ir sekretoriaus Jono Kriaučiūno pasirašytą "Atsišaukimą i

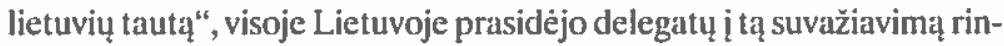
kimas, atrinkimas ar tiesiog rengimasis jame dalyvauti. Suvažiavo i ji apie 2000 atstovų. Pasitikéjimas kvietimu ir suvažiavime svarstomụ klausimụ programa atspindèjo jų tautinị integralumą ir aktualumą.

Didysis Vilniaus Seimas buvo išeitis iš valsčiaus ribose svarstytụ lietuviu politinių, tautinių ir socialinių problemų. Solidarumo ir bendros kovos poreikis buvo akcentuotas „Atsišaukime ị lietuvių tautą". Jame rašoma: „Lai būna garbẻ visiems kankiniams už laisvę ir žmoniụ gerovę! Dabar <...> susispieskime krūvon visi, kam rūpi prikẻlimas Lietuvos iš miego, iš neturto, iš tamsos, iš nusižeminimo!"

Pradėdamas Lietuvių suvažiavimą Vilniuje, Jonas Basanavičius pabrèžè vizualinio solidarumo svarbą. Jis kalbejo: „...mes jus Vilniun sukvietème ne tik tam, kad mes vienas su kitu susipažinę, patirti galétumém apie lietuviụ vargus, sužinoti, kas plačioje mūsụ Lietuvoje girdèti, bet ir idant atlikti ne menką tautišką darbą“" (291).

Remiantis Seimo delegatụ pasisakymais ir raštiškais priesakais, jo nutarimuose buvo pabrèžta, jog Rusijos vyriausybẻ „yra pikčiausiu mūsu priešu“ ir kad suvažiavime „dalyvavusieji lietuviai nutarè: šviestis, rištis ir stoti kovon drauge su sukilusia visų Rusijos tautų liaudimi“'. Kartu buvo iškeltas etninẻs Lietuvos autonominès valstybès su demokratiškai išrinktu Seimu Vilniuje reikalavimas. Tai buvo Lietuvos valstybingumo atkūrimo deklaravimas. Šis reikalavimas padẻjo vienytis tautai apie svarbiausią politini siekị.

"Organizaciniam komitetui buvo pateikti du - J. Basanavičiaus is P. Višinskio projektai. Buvo nutarta skelbti J. Basanavičiaus projektą ir po juo pasirašyti tik Organizacinio komiteto pirmininkui ir sekretoriui (Lietwiyl litemüros ir Iawosakos instituto biblioteka. F. 22, b. 1455, lap. 10-14). 
Seimo nutarimuose taip pat buvo iškelti kiti pagrindiniai ir ilgalajkiai tautos siekiai - dèl lietuvių kalbos teisès valsčiuose ir aukštesnése administracijos institucijose, mokyklose, lietuviụ teisių dirbti savo krašto švietimo, administracijos, teismų sistemoje. Buvo nurodyta, kaip griauti imperijos valdžią ir kurti naujają. Svarbus tautinio solidarumo akcentas buvo Seimo nutarimas, kad Suvalkụ gubernijos lietuviai, jụ apgyventa žemé būtụ atskirta nuo Lenkijos Karalystès ir prijungta prie autonominès Lietuvos.

Suvažiavimo nutarimai buvo paskelbti dienraštyje „Vilniaus žinios".

1905 m. pabaigoje beveik visoje Lietuvoje pradèta igyvendinti priimtus nutarimus: perrenkamos valsčių valdybos, teismai, naikinami karo prievolininkụ sąrašai, carụ portretai, uždaromos rusiškos mokyklos, šalinami iš Rusijos atsiųsti mokytojai, vietoje ju paskiriami lietuviai, šalinami policininkai, žandarai. Daugiausia tai buvo daroma sušauktụ susirinkimụ metu, vadovaujant Seimo mandatą turintiems jụ dalyviams. Iš Lietuvos provincijoje 1905 m. vykusių 237 mitingu ir didesniụ viešụ susirinkimu 177 (75 proc.) surengti gruodžio-sausio mén. Jie pasitarnavo demokratizavimo pletrai. Kauno gubernijoje tokie demokratizavimo pertvarkymai buvo 81 valsčiuje, 121 pradžios mokykloje, Suvalkijoj 33 gminose ir 47 mokyklose. Viešai niekas Rusijos valdžios negyné, nors ne visi, bijodami valdžios keršto bei represijų, ir pritarè pertvarkymams.

Solidari Rusijos valdžios vertimo ir jos pakeitimo kova buvo tokia plati, kad ji be kariuomenès negalẻjo atkurti savo režimo. Mobiliụ baudžiamujụ būriụ reidai ir represijos, suiminẻjant aktyviausius veikèjus, vadovus, kontribucijos už pasipriešinimą palaužè issisiūbavusị išsivadavimą. Sulaikytieji buvo baudžiami kalejjimu ir katorga. Amžininkai pastebèjo, kad tarp teisiamujų vyravo 30-50 metų, tai yra sąmoningiausio amžiaus gyventojai. Sukilimas buvo sąmoningas Lietuvos gyventojų valstybès kürimas. 


\section{Išvados}

1. Lietuvių politinẻs partijos $1905 \mathrm{~m}$. nesudarè vadovaujančio pasipriešinimui Rusijos valdžiai centro, išsivadavimas vyko vadovaujantis bendrais idealais. Jis vyko neperžengdamas valsčiaus visuomenès ir teritorijos.

2. Didysis Vilniaus Seimas išsivadavimo igyvendinimą išvedè iš valsčiaus arealo i visą Lietuvą. Tai buvo aukščiausias solidarumo etapas, demokratiškai iškẻlęs Lietuvos valstybès atkūrimą.

$3.1905 \mathrm{~m}$. lietuviụ sukilimas ir jo metu pasireiškęs solidarumas likvidavo Rusijos valdžios administracijos Lietuvos provincijoje funkcionavimą, o ji atkurti imperija galëjo tik karinémis represijomis. Kariuomenei galẻjo pasipriešinti tik ginkluota jëga.

4. 1905 m- tautinio sukilimo kultūriniai ir politiniai idealai, solidarumas buvo brangus lietuvių paveldas, kuris padejo 1917-1918 m. atkuriant nepriklausomą Lietuvos valstybę. 


\title{
THE EXPRESSION OF THE SOLIDARITY OF THE LITHUANIAN NATION IN 1905
}

\author{
ANTANas TYLA
}

\section{Summary}

Keywords: Revolt of 1905; national solidarity; delegates.

The author, reminding that even though the historic literature on the national revolution or revolt of 1905 in Lithuania (hereinater referred to as the revolt) is not abundant, basically its stages, the major forms of fight against Russia's oppression and for the liberation, as well as their territory dispersion and consequences when liquidating the functioning of Russia's government have been ascertained. Also, the local leaders of the revolt, the suppression of the revolt and repression" have been found out and the history of the Great Seimas of Vilnius has been processed monographically'. However, stressing that the development and possibilities of seience and historical literature are rising new issues of the cognition and assessment of this event, now without the ideological violence it is possible to deepen and widen the studies about this revolt objectively and more clearly.

The article discusses the common interests of the Lithuanian nation and its supporters in 1905, the territorial and ideological dispersion of solidarity and the traditions and novelties of the solidarity content.

The research and memories of the contemporaries of 1905 events confirm that the revolt that covered almost all Lithuania but that did not form a central body of the revolt like during the revolt of 1863 was based on the ideological solidarity. The dictionary of international words describes solidarity as the sense of community, unity, common interests and common responsibility.

Tyla, A. 1905 met! revolincija Liennos kaime. Vilnius, 1968; Tyla. A. Lictuvos valdymo 1900-1914 metais ypatumai. Lieturos TSR Moksly akademijos darboi, A serija. 1968, t. 2, p. $75-94$.

${ }^{10}$ Moticka, E. Didysis Vilniaus Seimas. Lieturi! alginimo isıorijos studijos. Vilnius, 1996, t. 11. 
These solidarity ideals accompanicd the uniting of Italy, Germany and Czech in the $19^{\text {th }}$ century and the creation of a unified state. The revolt of 1963 with its central body was also based on the idcological solidarity. Active actor of Lithuanian intelligentsia and publicist Vincas Kuditka called for unity for Lithuania's sake in his "National Song" written at the end of the $19^{\text {th }}$ century. The content of this song, which later became the national anthem was little known in 1905, even though during the concerts that began in this year "The National Song" used to be called for an encore by the audience 2-4 times". Undoubtedly, the solidarity the revolt of 1905 and its mentality could be predestined only by ambitions that sprang out of the everyday life and by the aspiration to realise them.

In 1905, the purposeful common actions of liberation and content were encouraged by several home and imperial government factors:

1. The attempt by the Russian government for reorgunisation and its use for the national liberation;

2. The propaganda by intelfigents and rural activists in public gatherings and the distribution of leaflets;
3. The organisation of the Great Seimas of Vilnius;

4. The mandate of trust of the nation received by the participants of the Great Seimas of Vilnius, the athority of resolutions and the development of their realisation.

The manifest of the Russian Tsar dated 18 February 1905 [s.st.] and the order to the Senate, by which it was allowed to submit proposals to the government, General Governors and Governors regarding the improvement of the regime apparatus and the improvement of nation's situation ${ }^{2}$, similarly like the so-called "perestroika" by Michail Gorbachov in the Soviet Union in 1984-1989 that provided the possibilities for the destruction of the Soviet empire, served for the criticism and the empire regime and its crisis. Most of the Lithuanians perceived the improvement of the situation as the abolition of Russia's colonial system in Litluuanja. The most active in this reform were the rural people and the intelligentsia. The farmers used to consider their proposals in the boarders of rural districts and lay them down in their petitions and resolutions adopted without the participation of officials of

1 Maciūnas, V. Lietuvos Himno istorijos bruožai. Lietmos Himnas. Vilnius, 2(X)5, p. 21, 23-25.

12 Полне собрание законов Российской инлерии. Санкт-Петербург, 1906, t. 25. This order was repealed by the manifest of 19 June 1905, which convened the Duma. 
the Russian government and send to the Russian govemment. They demanded the election of officials of the district without any restrictions, their responsibility to the voters and not to the heads, required the introduction of the Lithuanian language into the boards of districts and courts, the freedom of word, press, meetings and organisations and the convention of the Constituent Seimas or the Seimas in Vilnius elected by universal, direct and secret ballot.

More than by petitions, the Russian government was moved by the manifest of the Tsar dated 17 October tegarding the freedoms of expression, meetings, press and organisations. The Russian administration was confused and did not know what to prohibit or what to allow. It became even more dispersed, even soon after that the state of war was introduced in the Lithuanian districts of Suvalkaj government and in Kaunas government the state of emergency was preserved.

Making use of this manifest, the residents of Cypènaì district, Panevéżys county, removed the former officials and elected the new ones, demanded for the new convention of the Seimas of Vilnius and decided until this time to rule by themselves, i.e. announced the selfgovernment and broke relations with the government. The resolutions of the district were published in Vilniats Zinios
("Vilmins News") and made a big impression". They were different in substance from the content of the petitions. The residents of Čypenai were followed by the neighbouring district of Girsūdai.

The rnutual understanding and trust of the intelligentsia and national masses were most revealed during the preparations for the Convention of Lithuanians in Vilnius and the Great Seimas of Vilnius and during its course. It was enough to publish the Proclamation to the Lithuanian Nation in Vilhiaus Žinios ("Vilnius New's") and the election, selection of the delegates or simply preparations started to participate in the convention. The event gathered about 2000 participants. The trust in the invitation and the programme of issues to be discussed feflected the national integrity and topicality.

The Great Seimas of Vilnius was the exit from the political, national and social problems of Lithuanians discussed within districts. The need for solidarity and common fight was highlighted in the Proclamation to the Lifhuanian Nation. It says: "Let all martyrs for freedom and well-being of people be honoured! Now<...> let us come together all who cares about waking Lithuania up from sleep, from poverty, from datkness and from bumiliation!".

13 Tyla, A. 1905 mef!! revoliucija Lieturos kaime. Vilnius, 1968, p. 96-97. 
Starting the Lithuanian's Convention in Vilnius Jonas Basanavičius stressed the importance of visual solidarity. $\mathrm{He}$ said: "...we gathered you in Vilnius not only that after getting acquainted with each other we could experience the hardships of Lithuanians and to learn the news from our wide Lithuania, but also to make a significant nutional deed" [291].

On the basis of the statements and written precepts of the Seimas delegates, its resolutions highlighted that the Russian government "is our biggest encmy" and that "the Lithuanians who participated in the Convention decided: to educate themselves, to tic and rise up for the fight together with the people of Russia's nations".

The author draws the following conclusions:

1. In 1905 the Lithuanian political parties did not make a centre leading the resistance to the Russian government. The liberation took place on the basis of common ideals without crossing the society and territory of the district.

2. The Great Seimas of Vilnjus brought the liberation from the district to the whole Lithuania. It was the peak of solidarity rising the issue of the reestablishment of the state of Lithuania in a democratic way.

3. In 1905, the revolt of Lithuanians and solidarity coming with it liquidated the functioning of the Russian government administration in the province of Lithuania and the empire could only be re-established by using military repressions. The army could be resisted only with the armed force.

4. In 1905 the cultural and political ideals of the national revolt and the solidarity was a dear heritage of Lithuanians helping to re-establish the independent state of Lithuania in 1917 1918.

fleikta 2005 m. gnuodzio 4 d. 